\title{
Historical Configurations of Freemasonry in Belgium: Secularity, Politics, Fragmentation
}

\author{
Configuraciones Históricas de la Masonería en Bélgica: \\ Laicidad, Política, Fragmentación
}

\begin{abstract}
Jeffrey Tyssens
Docteur en Histoire. Professeur d'histoire politique contemporaine et Président du Groupe de recherche sur la maçonnerie, Vrije Universiteit Brussel, Belgique. E-mail : jeffrey.tyssens@vub.ac.be
\end{abstract}

DOI: http://dx.doi.org/10.15517/rehmlac.v8i1.24279

Fecha de recibido: 30 de noviembre de 2015 - Fecha de aceptación: 25 de enero de 2016

Palabras claves
Bélgica, la política, la laicidad, el género, la regularidad

Keywords

Belgium, politics, secularity, gender, regularity

\begin{abstract}
Resumen
Si la masonería belga era una sociabilidad a problemática durante una gran parte del siglo XVII, esta dinámica se transformó a partir de la anexión de Bélgica a Francia y a los Países Bajos a finales del siglo XVIII y durante las primeras décadas del XIX. Un conjunto de nuevas logias con una gran cantidad de nuevos miembros, principalmente burgueses generaron progresivamente una masonería que iba a ser cada vez más anticlerical y políticamente abierta como el núcleo duro del partido liberal del país. En este artículo muestra cómo durante la secularización de sus discursos y prácticas, el Gran Oriente belga estaba a la vanguardia de lo que comúnmente se llamó la masonería "latina". Sin embargo, aprincipios del siglo XX, cuando la democracia de masas cambió la identidad del país y las primeras simpatías socialistas se desarrollaron en las logias, se inició un proceso de despolitización, más o menos completado, después de la Primera Guerra Mundial. La configuración masónica belga entonces tendió a la fragmentación. Este proceso se inició a principios del siglo XX y continuó hasta los inicios del XXI, donde los debates sobre la cuestión de la regularidad y aún más por la impugnación de la exclusividad de género de las grandes logias masculinas por las masonerías mixtas o femeninas. Si bien se rompió la antigua unidad organizativa, sin embargo, se pudo desarrollar una convivencia relativamente benigna.
\end{abstract}

\begin{abstract}
If Belgian freemasonry was a largely unproblematic sociability during the $18^{\text {th }}$ century, it took a completely new direction since future Belgium's annexation to France and the Netherlands at the end of the $18^{\text {th }}$ century and in the first decades of the $19^{\text {th }}$. A set of new lodges with a largely new, mainly bourgeois membership gradually generated a freemasonry that was increasingly anticlerical and openly political as it was the backbone of the country's liberal party. This article shows that, in its secularizing of its own discourse and practices, the Belgian Grand Orient was at the vanguard of what is commonly called "Latin" freemasonry. However, at the turn of the $20^{\text {th }}$ century, when mass democracy changed the country's institutions and when the first socialist sympathies developed within the lodges, a process of de-politicization was engaged that was more or less completed after World War I. The Belgian masonic configuration then tended to become more fragmented. This process started in the early $20^{\text {th }}$ century and was continued into the early 21 th, with debates on the regularity issue and even more with the contesting of the male gender-exclusiveness of the grand
\end{abstract}


lodges by members of mixed or feminine freemasonry. Nevertheless, if the old organizational unity was broken, a relatively benign coexistence was developed.

Belgian freemasonry is often looked at by outsiders as merely a variety of the masonic constellation in France. A small country neighboring a large, formerly even imperial state, a partial linguistic similarity, the comparableness of its religious outlook: "logically", the little one would simply emulate the big one. While not completely wrong (the role of French refugees e.g. has been important for Belgian masonry in specific time settings), this perspective is nevertheless far too superficial and unconsciously reproduces that questionable view of history where ideas and practices generate in big countries and small ones passively follow their lead. This is definitely a distorted regard that pays no attention to the fact that smaller geographical units have their own agency and sometimes are even in advance of larger countries. This is certainly the case with Belgian freemasonry. Historically, Belgian freemasonry developed configurations that were certainly comparable with its French counterpart (up to a certain extent and for a considerable part of its mainstream), but it had its proper dynamics and its own chronology where Belgian masons not necessarily waited for things to move in Paris. Although evidently smaller in absolute numbers, the proportional dimensions of Belgian freemasonry have been quite large (i.e. in a European context), at least since the $19^{\text {th }}$ century. While indeed Belgian freemasons had a keen eye for developments in the neighboring countries, and definitely for the one that was culturally the closest to the classes that manned the lodges (the French speaking bourgeoisie, in a country where the majority spoke Dutch), the liberal institutions the state had developed since its independence more than once allowed them to be in advance of other settings where so-called "Latin" freemasonry took shape, France included. In terms of its secular and political outlook, this was definitely the case.

A first remark that has to be made is that freemasonry in Belgium is older than the Belgian state. Indeed, when Belgium became an independent country in 1830, freemasonry was a more or less thriving society since many decades already. If the foundation of the first lodges -dating from the 1740 s-remains rather badly documented ${ }^{1}$, it is clear nevertheless that this initiating society had been imported simultaneously from different countries. Some lodges derived directly from English freemasonry, others were founded by freemasons powered by French or Dutch bodies. In 1770, a first provincial grand lodge was founded for the Austrian low countries, but that provincial body was only a weak structure. The essence of Masonic life was to be found in the local lodges, of course, and at least from

\footnotetext{
${ }^{1}$ All global overviews of $18^{\text {th }}$-century freemasonry in what was to become Belgium have become very old now. One usually still has to use a book written by a cleric almost a century ago (and re-edited in 2006 by Labor). See: Bertrand Van Der Schelden, La Franc-Maçonnerie belge sous le régime autrichien (1721-1794). Etude historique et critique (Louvain: Librairie Universitaire, 1923).
} 
the 1760 s onwards they were clearly doing well ${ }^{2}$. It is important to understand why that was the case. It would be completely wrong to see the lodges' success as a kind of marker of a vanguard Enlightenment culture in the provinces that eventually were to become Belgium. The Austrian low countries were by no means an obscurantist region, replete with reactionary yokels: although intellectual life was still quite provincial, books and theatre plays by Enlightenment authors like Voltaire were relatively widely available for example ${ }^{3}$, but that does not imply that lodges and freemasons were more inclined than others to develop this particular cultural consumption. Although adequate research is lacking for the period, there are no clear indications that in this respect masons were really different at that time than other people with similar social backgrounds ${ }^{4}$. If one looks at the rare records of $18^{\text {th }}$-century low country lodges, their activities -at least the ones outside initiations and the like- look pretty uninspiring indeed, that is to say: the fun was to be found after the lodge meetings, in the meals, the collective drinking and singing. Hence the lodges of the Austrian period do not appear as the spearhead of Enlightenment, let alone radical Enlightenment. They were definitely no "sociétés de pensée", to use the particular concept

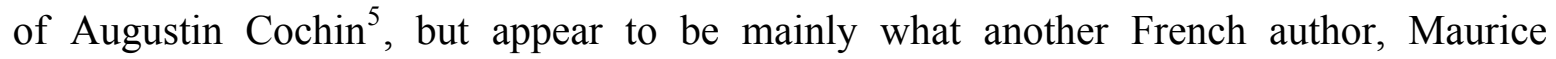
Agulhon, qualified as "sociabilités", mainly of relatively wealthy stock.

But how then did Belgian (or proto-Belgian) freemasonry transform into an associative network that would very definitely act as "sociétés de pensée" with the progressive, secular and even an outspoken militant character, that would typify it from the $19^{\text {th }}$ century onwards? Two elements have to be taken into account here. One is the role of Catholicism. The second is the deep impact of the French Revolution in the southern low countries. Let us start with the Catholic Church. It is well known that the pope condemned freemasonry quite early: in 1738, with the apostolic constitution "In Eminenti", pope

\footnotetext{
${ }^{2}$ For the $18^{\text {th }}$-century Austrian low countries, well documented lodges are preciously few, even for that post1760 period when they proved more sustainable. One of the best kept record collections for that epoch concerns a lodge in the small town of Aalst. See the recent study: Herman Van Isterdael, Geschiedenis van de vrijmetselaarsloge La Discrète Impériale te Aalst (1764-1786) (Aalst, 2014).

${ }^{3}$ Some even referred to a «Flemish Enlightenment». See: Luc Dhondt, “Oost-Vlaanderen", in Hervé Hasquin (dir.), Het culturele leven in onze provincies in de $18^{e}$ eeuw, Brussels, Gemeentekrediet, 1983,133 e.s. Mostly people would relate to a moderate, Catholic Enlightenment.

${ }^{4}$ That lodges were no vanguard of course does not imply that no freemasons were involved in the spreading of Enlightenment ideas. A fascinating example can be found in the character of lawyer Jean-Baptiste Le Cat (1744-1818), member of the lodges La Candeur and later La Constante Union in Ghent, who was the editor of Den Vlaemschen Indicateur, an important enlightened periodical in the low countries during the late 1770s and 1780s. See: Guy Schrans, Vrijmetselaars te Gent in de XVIIIde eeuw (Ghent: Liberaal Archief, 1997), 317-322.

${ }^{5}$ On Cochin and his perspective on the lodges of that epoch, see : Fred E. Schrader, Augustin Cochin et la République française (Paris: Seuil, 1992), 24-29, 177-226.

${ }^{6}$ Maurice Agulhon, Pénitents et Francs-Maçons de l'ancienne Provence (Paris : Fayard, 1968), 161 e.s.

${ }^{7}$ There were some adoption lodges for ladies though. Fairly little is known about them.
} 
Clement XII excommunicated ipso facto all freemasons, notably because men of different religions could meet on the basis of equality and tolerance ${ }^{8}$. Now what is so interesting about the "Belgian" provinces of the 18th century is that this papal constitution was considered to be non-applicable there because the Austrian emperor had not given his "placet", a kind of authorization which was requested to make it valid for that territory. The consequence was that the lodges were filled with practicing Catholics who did not at all see their Masonic membership as problematic -even a couple of clergymen were affiliated. There are very clear indicators that the existence of the papal constitution "In Eminenti" was well known, but that these Catholic freemasons simply looked the other way, which might be an indication of a relatively latitudinarian approach of their religion, at least for a significant part of them ${ }^{9}$. Another interesting aspect is the fact that they did not mind to sit together with Protestant and Jewish freemasons, who were not largely present as they only constituted very small communities in a couple of cities, but still, there are interesting examples, the lodge of port town Ostend for instance, where a handful of nonCatholics were members indeed ${ }^{10}$. So, if militant defenders of radical Enlightenment were rare or simply absent, the people who frequented the lodges at least accepted the norm of a relative tolerance. One way or another, this had to lead to problems with the Catholic hierarchy.

This was to become all too clear when the French Revolution was affecting the future Belgian provinces. Here again, the historical development has been quite specific. First of all, in 1789 southern low country freemasonry had been nearly strangled because in 1786 Austrian emperor Joseph II had imposed one of his reforms upon it, i.e. to concentrate the entire freemasonry into three lodges in Brussels, thereby killing what was then its main feature, i.e. local social intercourse. Second, the southern low countries, mainly Brabant, had their own revolution in 1789 , but it was more of a reactionary one, directed against some other, more enlightened reforms of that same Emperor Joseph. This brought a period of deep turmoil, which eventually led to the take-over and annexation of the region by revolutionary France in 1795. The 20 years of French rule would bring a renaissance of freemasonry (most of the older lodges which are still functioning today have been founded during the French epoch) but it was not to be exactly the same freemasonry as we saw before emperor Joseph's decrees of 1786. Once the Dutch took over for the 1814/15-1830 period, freemasonry continued to do well and reinforced the tendency towards structural

\footnotetext{
${ }^{8}$ It is clear though that the pope acted also as so many other worldly leaders that were just as suspicious with regard to this new society. See: José Antonio Ferrer Benimeli, "Franc-maçonnerie et Eglise catholique. Motivations politiques des premières condamnations papales", Dix-huitième Siècle 19 (1987) : 7-19.

${ }^{9}$ Jacques Lemaire, "Franc-maçonnerie et religion en Flandre et dans les pays-bas autrichiens pendant le XVIIIe siècle", Franc-maçonnerie et religions dans l'Europe des Lumières, Charles Porset and Cécile Révauger eds. (Paris : Champions, 2006), 157-164.

${ }^{10}$ Raoul Vantomme, La vie de la loge Les Trois Niveaux établie à l'Orient d'Ostende depuis 1784 (Ostend: 1986), 2 Volumes, passim.
} 
change engaged under the French. First of all, the aristocratic element was quickly disappearing. More and more, lodges were becoming populated by the bourgeois and the middle classes, with usually a strong presence of officials of the respective regimes ${ }^{11}$. Until Waterloo, everything functioned under the auspices of the Grand Orient de France, which made that the Napoleonic tentative to politically "instrumentalise" freemasonry was also to affect the Belgian lodges ${ }^{12}$. Once the Dutch Grootoosten der Nederlanden took over after 1815 , that same policy (with the Dutch king imposing his youthful son, prince Frederik, as the Grand master) would continue -in this particular case: keeping north and south together by integrating at least part of the elites by means of the lodges ${ }^{13}$. In both cases though the political authorities who tried to use freemasonry for their own purposes were not in a very good standing with the Catholic Church that dominated religious life in the region. Consequently, tensions between freemasonry and parts of the local clergy were gradually growing and once the French cleared the space for the Dutch in 1814-1815, these tensions would lead to a number of the first outright confrontations.

No doubt, the mythical association of freemasonry with the French Revolution and Jacobinism, as it was made by a number of priests like the famous abbé Barruel and had been spread by books and pamphlets, was starting to produce a major rift. In the 15 years before Belgian independence, we find a couple of examples where priest-led mobs tried to sack lodge buildings ${ }^{14}$, a completely unknown phenomenon before the Revolution, but the most important new thing was the introduction of religious sanctioning of freemasons in the Belgian provinces. This sanctioning was not imposed by the bishops yet but was the initiative of the more fanatical strands of the local clergy. It was effected through the refusal of sacraments to freemasons -who were still in large majority practicing Catholicsand most of all by the so-called "refus de sépulture", i.e. the refusal of the clergy to provide a religious burial to deceased masons (making it difficult to get someone decently buried altogether), which caused an ever growing indignation and resentment. The most striking example was surely the "imposed" civil burial ${ }^{15}$ of French freemason and former

\footnotetext{
${ }^{11}$ An interesting local study on that phenomenon with regard to the Flemish city of Kortrijk can be found in: Andries van den Abeele, De Kortrijkse vrijmetselaarsloge L'Amitié 1803-1833 (Kortrijk: De Leiegouw, 1989).

${ }^{12}$ Eric Saunier, "La Franc-maçonnerie et l'Etat napoléonien : de l'instrumentalisation à la recomposition", in La Franc-maçonnerie sous 'Empire. Un âge d'or ?, Pierre Mollier ed. (Paris: Dervy, 2007), 139-148.

${ }^{13}$ Anton van de Sande, Vrijmetselarij in de lage landen. Een mysterieuze broederschap zonder geheimen (Nijmegen: Walburg Pers, 2001), 103-115.

14 This charivari-like practices were limited to some small provincial towns. See: Jeffrey Tyssens, "AAdorateurs du diable'. Over vrijmetselarij en levensbeschouwing", idem (ed.), Van Wijsheid met Vreugd gepaard. Twee eeuwen vrijmetselarij in Gent en Antwerpen (Brussels / Ghent: Marot / Tijdsbeeld, 2003), 9596.

${ }^{15}$ Civil burials that were chosen for by a moribundus or by his descendants still were very exceptional back then and were hardly to be found for freemasons yet. For an example of a voluntary burial -of a non-masonwithout church assistance in the early days of French annexation, see e.g.: Hugo De Schampheleire, De Antwerpse vrijmetselaars in de $18^{e}$ eeuw (Antwerp: Ontwikkeling, 1969), 96.
} 
revolutionary Louis-Pierre Saint-Martin in Liège in 1819. The masonic records of those years were most revealing in that respect: the clergy's refusal to bury Saint-Martin with a religious service provoked sharp outbursts in the lodges ${ }^{16}$. By contrast to the $18^{\text {th }}$ century, an explicitly anticlerical discourse was gradually appearing in the 1810 s and 1820 s. Several lodges were constituting lodge libraries where books by anticlerical Enlightenment authors were now definitely part of the collection ${ }^{17}$. So clearly the atmosphere was changing. It is quite a paradox that in those Dutch years the influence of more radical French ideas was perhaps stronger than during French annexation. The presence of a number of rather influential French political refugees was most important in that respect and has certainly contributed to a starting transformation of masonic life, notably in cities like Ghent or Liège and even more so in Brussels. This French element did not only affect the ideas, but also the masonic practices. What was extremely important -as it touched the core of lodge activities later in the $19^{\text {th }}$ century and was to remain present until today- was the introduction by these French ex-revolutionaries of speeches on non-masonic subjects into the ritual lodge meetings, i.e. what was to become the new style "morceau d'architecture" or "planche", an essential part of the debating culture, i.e. a social and political debating culture, which would remain an essential feature of so-called "Latin" freemasonry. These first talks, which they still called "conférences" in those days, treated rather innocent subjects like the natural sciences, but it would not take too long before religion and politics would appear as well ${ }^{18}$.

Once Belgium became an independent country in 1830, practically all elements were present to make freemasonry not only genuinely "national", but also very much engaged as a secular political force in society. The creation in 1832-1833 of the Grand Orient de Belgique out of the remnants of the southern administrative grand lodge installed by the Dutch during their 15 year rule was somewhat painstaking, as the Belgian lodges had not gone through the 1830 revolution and the subsequent independence of the country without considerable trouble. Protagonists of the continuation of Dutch rule confronted militants of Belgian independence within the lodge rooms, often leading to lodges closing down, at least temporarily. Other lodges, mainly in Ghent, even proved to be hotbeds of "Orangist" resistance (referring to the name of the Dutch royal family) against the new state. It was to take a good many years before the new grand lodge was to federate all lodges on

\footnotetext{
${ }^{16}$ Annales maçonniques, littéraires et historiques de la maçonnerie des Pays-Bas à dater du 1er janvier 1814, 1824, Volume III, 507-557.

${ }^{17}$ We have a good example with the lodge library of the Ghent Vrais Amis in the early 1820s. See: Jeffrey Tyssens, "Van Wijsheid met Vreugd gepaard'. Twee eeuwen vrijmetselarij in Gent en Antwerpen", in Van Wijsheid met Vreugd gepaard. Twee eeuwen vrijmetselarij in Gent en Antwerpen, Tyssens ed. (Brussels / Ghent: Marot / Tijdsbeeld, 2003), 36-37.

${ }^{18}$ Tyssens, "Aspects de la sensibilité libérale dans les loges belges pendant les premières décennies du XIXe siècle", Lumières 7 (2006): 181-195.
} 
Belgian soil ${ }^{19}$. Whatever this constellation might have brought as problems for the Grand Orient de Belgique, it nevertheless became a political actor of importance quite rapidly. In spite of everything, the options of the founders of the Grand Orient still had a rather "traditional" appearance, as they did not state a political goal for this new national body. Indeed, the article 135 of the Grand Orient's constitution explicitly maintained the formal prohibition of political and religious discussion within the affiliated lodges. Very soon though, this article would prove to be largely redundant in practice.

First of all, a number of lodges of the Liège province -lodges with a quite militantly liberal outlook- refused to join the Grand Orient, precisely because of this prohibition. And within the Grand Orient itself, it was all too obvious that a number of lodges -most importantly the large Brussels Amis Philanthropes lodge- were closer to the Liège-type of stance than to the traditional a-political one. This was clearly shown, immediately in the 1830s, through the escalating confrontation with the Catholic Church, for whom independent Belgium with its constitutional system brought much larger possibilities to realize its ideological and political project than the French and Dutch regimes had done. The liberal opinion would react against that and, as we will see, the lodges would eventually become the organisational backbone for that ideological stance. This was most eloquently shown in the educational conflict, "la lutte scolaire",20, which was the first matter where a major public intervention of the masonic bodies was to have important consequences. When the bishops made use of the newly introduced freedom of education to open a catholic university in Mechelen in 1833 -at a time when it was not sure at all that the existing state universities would be maintained, what might have implied a Church monopoly on higher education- it was precisely the Brussels freemasons who gave an adequate answer to that threat. In 1834, the Brussels Amis Philanthropes lodge and its worshipful master Pierre-Théodore Verhaegen, a key figure in 19th century Belgian freemasonry, took the initiative to create the Université Libre de Belgique (later: Université Libre de Bruxelles), a higher education institution which still exists and which had the principle of free inquiry as its basic principle and opposed a Catholic higher education project explicitly rooted in papal doctrine. For several decennia, Belgian freemasonry was the main fundraiser for this university which was and has remained essential to secular

\footnotetext{
${ }^{19}$ By the 1840s, when relations between young Belgium and the Netherlands tended to normalize gradually, the "Orangist" tradition had quickly become a matter of folklore rather than a politically relevant choice. Furthermore, most lodges that had remained loyal to the Grootoosten der Nederlanden closed down by the mid-1850s. However, the leading "Orangist" lodge, the Ghent Septentrion, kept out of the Belgian grand lodge until the 1880s. See: Herman Balthazar, "De Gentse brandhaard. Orangisme en vrijmetselarij", Tyssens ed., Van Wijsheid met Vreugd gepaard, 71-87.

${ }^{20}$ A general overview of the conflict can be found in Tyssens, Om de schone ziel van 't kind ... Het onderwijsconflict als een breuklijn in de Belgische politiek (Gent: Provinciebestuur Oost-Vlaanderen / Liberaal Archief, 1998). (Bijdragen Museum van de Vlaamse Sociale Strijd, 15).
} 
people in Belgium ${ }^{21}$. If one just reminds of the implication of Brussels' university in the first debates on Darwin's ideas in this predominantly Catholic country (at first rejecting them because of positivist influences within the university staff ${ }^{22}$, then it is immediately clear how important this masonico-educational project has been for the growth of nonreligious worldviews.

The Belgian bishops quickly understood the potential of freemasonry as a force opposing its confessional project for new Belgium and reacted vehemently, against the "Université Libre" of course, but also against freemasonry in general. Where they had never made public statements on the matter before, they did now, more in particular in December 1837 when they issued a collective letter to the faithful, aggressively condemning freemasonry and prohibiting Catholics to become or to stay members of a masonic lodge -sacrament refusal again being the arm to enforce the interdict ${ }^{23}$. Now this is a most interesting episode, if we keep in mind that in 1837 the large majority of Belgian freemasons, although clearly anticlerical, still were practicing Catholics. Even staunch anticlerical like Verhaegen himself attended mass every Sunday almost until the end of his life $^{24}$ and he was certainly no exception. So one might expect the anathema of the bishops to empty the lodges. This did not happen. Only very few freemasons handed in their aprons. The others remained freemasons, gradually radicalized their opinions, became ever more pronounced liberals and eventually (but certainly not immediately!) abandoned Catholic faith altogether ${ }^{25}$. Freemasonry became the crucible of a broad project to oppose the Church as a political actor, and more and more as a religious body as well.

For the Belgian lodges and the Grand Orient, this had two important implications. First of all, freemasonry would involve itself directly in party politics. Secondly, though a little later in the chronology, masonic ritual and "doctrine" -if one may call it like thatwould be largely secularized. Both were to have their effects in the broader masonic world, as a host of other masonic bodies did not understand the reasons behind this development and finally were to break their relationship with the Belgian Grand Orient -although that story is slightly more complicated than one usually hears it being told, as we will see further on. But let us first look at this double process of politicisation and secularisation within the Belgian lodges. Almost immediately after the Episcopal condemnation, a group of prominent liberal freemasons around the same Verhaegen we mentioned before, chose a

\footnotetext{
${ }^{21}$ John Bartier, "L'Université libre de Bruxelles au temps de Théodore Verhaegen”, Lä̈cité et francmaçonnerie, Bartier ed. (Brussels : Editions de l'Université, 1981), 13-71.

${ }^{22}$ Pierre F. Daled, Spiritualisme et matérialisme au XIXe siècle. L'Université Libre de Bruxelles et la religion (Brussels : Editions de l’Unversité, 1998), 142 e.s.

${ }^{23}$ Bartier, "La condamnation de la franc-maçonnerie par les évêques belges en 1837", Lä̈cité et francmaçonnerie, 225-232.

${ }^{24}$ Jean Stengers, "De filosofische en godsdienstige opvattingen van Verhaegen", in Pierre-Théodore Verhaegen 1796-1862 (Brussels: VUBPress, 1996), 121-130.

${ }^{25}$ Marcel De Schampheleire, Histoire de la franc-maçonnerie belge depuis 1830. Un siècle et demi de Grand orient de Belgique. Tome 1 : période de 1830-1914 (Brussels : GOB, 1987), 77-100.
} 
specific strategy for the future ${ }^{26}$. As the Catholic Church provided for a structure leading political Catholicism, a counter-veiling power was to be created on the liberal side: in their minds, freemasonry presented itself not simply as the only available instrument of structuring liberal opinion, the masonic ideals of tolerance and individual liberty made this option into a kind of moral duty, as they feared - not without some reason, by the way- that Catholic clericalism would pervade the country and its institutions, eventually turning Belgium's liberal constitution into an empty shell. Political problems were to be discussed in the lodge meetings and these debates could then inspire collective action. In a first stage, a host of lodges created local electoral committees to support liberal candidates. Then, in 1846, all of these committees joined to create the Liberal Party, the first modern political party of the country. The party and the local liberal associations were profane bodies, obviously, but their synergy with the lodges was intense. When the Grand Orient abandoned its old article 135 prohibiting political and religious discussion in the lodges, a decision taken in 1854, the principle was already without any significance for several years $^{27}$.

The vendetta with the Catholic Church gradually led Belgian freemasons to cut off all links with the old faith. They stopped going to mass and started to refuse all ecclesiastical interference with their lives. Here again, burials were highly symbolical events. Where in the 1840 for instance non-Catholic burials of freemasons were still more or less imposed by clergymen refusing to assist or bury masons who did not swear off their masonic qualities ${ }^{28}$, freemasons later tended to refuse themselves to have religious funerals, mainly since the 1860 s, the much discussed civil burial of the eternal Verhaegen being the big event marking that break $^{29}$. Some freemasons became protestants in those years, but they were only a minority ${ }^{30}$. Most of them kept, at least in a first stage, a vague, deist belief in a supreme being and in the immortality of the soul. Both elements being present in the masonic traditions, it was almost as if freemasonry became an alternative religion. But things evolved quite quickly into a more clear break with religion altogether. Even if this masonic spirituality remained present for a significant part of the Belgian freemasons for

\footnotetext{
${ }^{26}$ Bartier, "Théodore Verhaegen, la franc-maçonnerie et les sociétés politiques", Laïcité et franc-maçonnerie, 75-159.

${ }^{27}$ André Miroir, "Franc-maçonnerie et politique en régime censitaire. Essai sur l'abrogation de l'article 135 des Statuts et règlements généraux (1854-1870)", in Visages de la franc-maçonnerie belge du XVIIIe au XX siècle, Hervé Hasquin ed. (Brussels : Editions de l'Université, 1983), 229-244.

${ }^{28}$ Roger Desmed, "L'évolution du sentiment religieux chez les Francs-Maçons belges entre 1830 et 1914. L'exemple des loges bruxelloises", Problèmes d'histoire du christianisme VII (1978) : 69-70 ; Tyssens, "Pratiques funéraires. La sécularisation des derniers instants", Bruxelles. Les francs-maçons dans la cité, Despy-Meyer, A. dir. (Ghent : Tijdsbeeld, 2000), 201.

${ }^{29}$ Tyssens and Marie-Pierre Verhaegen, «De dood van Pierre-Théodore Verhaegen », in Pierre-Théodore, 151-169.

${ }^{30}$ Hugh Boudin, "Goblet d'Alviella et le protestantisme libéral", in Eugène Goblet d'Alviella, historien et franc-maçon, Alain Dierkens ed. (Brussels : Editions de l'Université, 1995), 35-49 (Problèmes d'histoire du christianisme, 6).
} 
many decennia (mainly in high degree Masonry), more and more amongst them shifted to agnosticism or even to atheism. Based on a study of 19th century Masonic funerary rituals quite intensely, that shift mainly took place in the $1870 \mathrm{~s}^{31}$. That was precisely the decennium when Belgian freemasons -advancing even their French counterparts- changed their ritual ways of working to make them more acceptable for agnostics and atheists: within the Grand Orient, the invocation of the supreme Architect of the universe was no longer obligatory to the lodges but merely optional; the same goes for the presence of a bible during lodge meetings and finally candidates were no longer supposed to believe in the immortality of the soul ${ }^{32}$.

It is often said that these elements led to a breaking off of the relations of the Belgian Grand Orient with the United Grand Lodge of England, but that is not correct, as there simply were no relations to break in the first place. The story is more confusing, as it was precisely in the 1870s, when Belgian freemasons were hyperactive in politics and secularized their ritual context in a quick pace, that a rather loose link with the English grand lodge was established, incidentally in a period when a highly controversial conversion of an English Grand Master to "popery" seemed to incite to a temporary understanding of the motives Belgian masons had to do what they were doing ${ }^{33}$. It was only at the whereabouts of the First World War, when Belgian masons were getting far less involved in politics than before, that the UGLE would break off relations (the decision was taken in 1908, but it was only rendered public after the war) ${ }^{34}$. However much this issue was to be at stake after World War Two, it was not at all preoccupying Belgian freemasons in the 19th or early 20th century. What mattered was confronting the clerical juggernaut on the home front, and if this or that English or German or American obedience broke off relations because of options taken in that specific Belgian context, the very large majority of Belgian freemasons could not care less.

This should not lead to the conclusion that the processes of getting ever more involved into liberal and anticlerical politics were self-evident at every stage. If Belgian freemasons had little other options than to confront their Catholic opponent, the process of

\footnotetext{
${ }^{31}$ Tyssens, « Sur les rites funéraires de la franc-maçonnerie belge du XIXe siècle », REHMLAC 3, no. 1 (mayo-noviembre 2011): 160-182 [Access March 17, 2016]: available in http://revistas.ucr.ac.cr/index.php/rehmlac/article/view/6591/6282

${ }^{32}$ L'Invocation du Gr(and) Arch(itecte) de l'U(nivers) dans les Loges dépendant du Grand Orient de Belgique, Brussels, GOB, 1935; Marcel de Schampheleire, Histoire de la franc-maçonnerie belge depuis 1830. Un siècle et demi de Grand orient de Belgique. Tome 1 : période de 1830-1914 (Brussels : GOB, 1987), 184-197.

${ }^{33}$ Goblet-d'Alviella had been most instrumental in creating that timid but nevertheless quite revealing connection/ See: Eugène Goblet d'Alviella, "Souvenirs de cinquante années de via maçonnique en Belgique (1870-1920)", Bulletin du Suprème Conseil de Belgique (1921) : 54 e.s.

${ }^{34}$ Jacques Lemaire, "L'abandon du Grand Architecte de l'Univers par le Grand Orient de Belgique", Charles Porset (ed.) Studia Latomorum et Historica. Mélanges offerts à Daniel Ligou (Paris : H. Champion, 1998), 295-312.
} 
politicisation was highly problematic for Belgian freemasonry as such, as it did not only bring freemasonry into politics, it also brought politics into freemasonry. That might sound banal, but it is not. The relatively sharp divisions which existed within Belgian liberalism, i.e. the conflict between a "doctrinaire" right wing and a "progressiste" left wing of radicals, eventually even with some fractions in between those two wings, started to divide freemasonry as well, sometimes even more than it did the liberal party, as the leftist tendency was stronger in the lodges than it was in the party. The result was frequent quarrelling, the splitting of lodges, low attendance of the members, lodges leaving the Grand Orient and what have you ${ }^{35}$. Belgian freemasons themselves reacted to these problems. If a more or less general consensus had grown around the secular, anticlerical character of the Grand Orient and its lodges, if a more or less general consensus existed as well on the freedom of discussion in the lodges, which obviously meant that religion and politics could be treated, a fundamental divergence existed around the consequences to be drawn out of the political discussions. The basic question was to be formulated as follows: could a lodge, casu quo a grand lodge like the Grand Orient, vote a political programme which was to be binding upon its members?

This discussion lingered on from the 1850s up to the 1890s when, all of a sudden, the balance rather quickly tilted over to a negative answer. The principle has sometimes been called the "Belgian system" in those days and was formulated as follows: whereas politics were concerned, "Les loges discutent, mais elles ne votent pas", the lodges discuss but they do not vote. And the same went for the grand lodge ${ }^{36}$. So, large numbers of Belgian freemasons became convinced that this was the only way not to allow politics to split freemasonry on ideological lines. That this happened in the 1890s is no coincidence. Not only is this the decennium when tax based voting was abandoned for a toned down form of general suffrage. It is also the period when a significant numbers of "progressiste" freemasons abandoned liberalism and became active members of the Belgian labour party. In this constellation, political differences within Belgian freemasonry had become so considerable, that political consensus on particular issues had become virtually impossible, with this one exception, at least for the time being, i.e. the opposition against the hereditary enemy, Catholic clericalism. And even there things became less evident after a while. Once liberals and socialists became potential coalition partners of the Catholic party in government during and after the first world war, even this traditional rallying point for collective action was no longer considered to be something a lodge or a grand lodge could

\footnotetext{
${ }^{35}$ See e.g. the sharp confrontations between the freemasons of the Walloon city of Verviers Schampheleire, Histoire de la franc-maçonnerie belge depuis 1830, 159-170.

${ }^{36}$ On that debate see Tyssens, "Sous le signe du progrès. Une histoire de la Loge gantoise «La Liberté $\mathrm{N}^{\circ} 4$ »", in R: L: La Liberté. Or:. de Gand, 5866-5991 (Gent, 1991), 33-46.
} 
decide upon. So clearly, after world war one, the process of relative de-politicisation of Belgian freemasonry was more or less concluded ${ }^{37}$.

It must be added that Belgian freemasons did not feel easy about this, even if it actually helped to preserve their unity -at least provisionally. It is quite striking how frequently the post-World War One discussions evolved around the theme of regaining the "old glory", or as they called it, the "rayonnement" freemasonry had had in the 19th century. That "glory" was partly mythical, even if one should not underestimate the role freemasons did play in the defense of public education for instance, or in the support of general suffrage, but the reference showed clearly that it was not altogether clear what direction freemasonry had to take for the future, what use masonry would have in society if it was not to do more than just endlessly talk about the problems of the day ${ }^{38}$. A late remnant of that preoccupation lingers on today in the discussions which return every now and then, at least in the Grand Orient. It is striking that, in comparison with e.g. France, these public statements have remained very rare since World War One. That does not mean that social and political problems were or are no longer discussed upon, on the contrary, but they do not or only very exceptionally lead to public statements, let alone to collective action schemes which have been abandoned altogether. This does not preclude individual action based on masonic inspiration however. It is clear for instance that the creation of the Humanist League in 1951 -a new secular society active in the north of the country- was the result of discussions and subsequent action of a postwar network of Flemish freemasons ${ }^{39}$.

The diminishing societal impact of Belgian freemasonry in the $20^{\text {th }}$ century must be related to another phenomenon: its tendency towards an ever larger fragmentation. Two elements have been at the heart of this process: the gender issue and the regularity debate. Remarkably enough, linguistic tensions did not significantly affect masonic structures in Belgium $^{40}$. One would certainly have expected otherwise in a country where this major political cleavage eventually led to a dismantling of the originally unitary state structures in favor of a federation with a far going devolution of competences towards regions and communities $^{41}$. The purely masonic issue of regularity had an important impact though. As

\footnotetext{
${ }^{37}$ Tyssens, Strijdpunt of pasmunt? Levensbeschouwelijk links en de schoolkwestie, $1918-1940$ (Brussel: VUBPress, 1993), 220-227.

${ }^{38}$ That was shown notably by the relatively passive attitude of the lodges when confronted with rising fascism Nazism or other forms of authoritarianism. See notably: André Miroir, "La franc-maçonnerie et la guerre d'Espagne (1939-1939)", Belgisch Tijdschrift voor Nieuwste Geschiedenis 1-2 (1987) : 481-495.

39 Jan Fransen, "Het Humanistisch Verbond: ontstaan, uitbreiding en crisis (1951-1961)", Belgisch Tijdschrift voor Nieuwste Geschiedenis 3-4 (1998): 499-525.

${ }^{40}$ If the introduction of Dutch as a working language for most of the lodges in Flanders and some in Brussels did not always pass without conflict and if bilingualism had some trouble getting really introduced within the grand lodges, language never became a major issue in Belgian freemasonry. See Tyssens, "Vrijmetselarij", Nieuwe Encyclopedie van de Vlaamse Beweging (Tielt: Lannoo, 1998), vol. III, 3585-3594.

${ }^{41}$ At most, some informal meeting regional forums have taken form within the grand lodges, but they do not possess genuine attributions. Regional and linguistic equilibriums are respected as well in the succession of grand masters and grand officers of the grand lodges.
} 
we already mentioned, it is quite striking that before the Second World War, the large majority of Belgian masons were pretty much indifferent towards the regularity issue. That changed profoundly in the cold war years: then, for very diverse motives, a number of Belgian masons wanted to get back into the Anglo-American mainstream. The motivations were complex and were certainly not always made explicit. If masonic traditionalism did play for some, the majority seems to have been moved by the new international constellation of the postwar years ${ }^{42}$. With the United States as the economically and politically hegemonic power in the west, it became attractive, at least to some, to swap their old alliance with the Grand Orient de France for a new link with the so much larger grand lodges of the Anglo-American world (more than 4 million American freemasons in $1959 . .$.$) , whether it was because of the potential finding of new business contacts on the$ other side of the Atlantic or because of their willingness to integrate Belgian freemasonry into some kind of a spiritual western alliance against the USSR and its godless friends. It must be added that a certain tendency towards democratization within at least some of the Belgian lodges after 1945, with new generations of notably teachers arriving, quite often with more socialist (or sometimes even more radical) leanings, was not very much to the liking of the more elitist lodges that already had a tendency toward more right-wing, Atlantic sympathies anyway.

The result of it all was a split in the Grand Orient in 1959 with the creation of a new Grand Lodge of Belgium that was recognized -after some years of probation- by the $\mathrm{UGLE}^{43}$. But this did not last very long. The vast majority of the Grand Lodge members were not very different in their philosophical opinions than their Grand Orient counterparts: as it had been assured to them by the representatives who had negotiated with Great Queen Street in 1959, most continued to see the supreme architect and the like as mere symbols, not as articles of faith ${ }^{44}$. Eventually the Grand Lodge of Belgium lost its recognition: the presence of agnostics and atheists could not remain unnoticed in the end, as was to be proven in the 1970s. This led to a new split off with the creation in 1979 of the Regular Grand Lodge of Belgium, which remained a quite small organization, often plagued by masons or even complete lodges leaving it, whether to join the "liberal" bodies or quitting freemasonry altogether.

\footnotetext{
${ }^{42}$ In quite some of the lodges that eventually broke with the Grand Orient, the character of day-to-day lodge meetings had not really changed in the 1940s and the 1950s, with the exception of a reintroduction of the use of the bible and the invocation of the grand architect - not as landmarks but as symbols, free for everyone to interpret, a problematical issue as was to be shown later on.

${ }^{43}$ To keep things sufficiently clear, we will not treat the even more complex issue of the implication of and consequences for high degree masonry of this regularity conflict. It must be understood however that international contacts of Scottish Rite masons have been extremely important for the dynamics behind the 1959 ruptures.

${ }^{44}$ Symbol versus landmark, that is. That the bible etc. were to be seen as symbols had been communicated to the Belgian masons and that principle drew part of them into the rupture scenario of 1959. In London the opposite had been affirmed. It is obvious that lies were told by those who acted as brokers in this process.
} 
The gender issue appeared earlier in the $20^{\text {th }}$ century and eventually had even more profound effects. The possible entry of women in the lodges had sporadically been touched upon in the $19^{\text {th }}$ century but it never found much support. The generalized gender inequalities were met by the masonic rejection of a Catholicism that was ever more perceived as a feminized religion: both elements acted decisively against a more open attitude. There were some feminists though, notably Henri La Fontaine of the Brussels Amis Philanthropes lodge, who advocated the introduction of a mixed freemasonry of the Droit Humain-type. Several Belgian women had been initiated abroad and eventually a mixed lodge of the Droit Humain was installed in Brussels in $1911^{45}$. The Belgian federation of Le Droit Humain was founded in 1928 and accompanied the step-by-step growth of mixed lodges outside Brussels. Most of the masculine lodges of the Grand Orient remained relatively hostile to this newcomer -the only more liberal signals came predominantly from Flemish lodges- and it lasted until the late 1960s before the Grand Orient showed more willingness to a certain rapprochement ${ }^{46}$. Since about 15 years, after a long period of debates and sometimes of conflicts with more radical lodges in Flanders, the Grand Orient has given its lodges a large autonomy in accepting women masons as visitors: this liberty has been implemented mainly in the north of the country. A certain tendency in that same direction, be it still quite timid, can be observed in the Grand Lodge.

But even more significant transformations have touched the masonic sphere outside the masculine grand lodges. The Belgian Droit Humain has grown considerably and has become the second largest grand lodge of the country (7333 members), behind the Grand Orient (10169 members) but significantly larger than the Grand Lodge of Belgium (4035 members) and even more than the Regular Grand Lodge (1755 members) ${ }^{47}$. Then, it has become more genuinely mixed, the lodges being no longer populated merely by spouses of members of the masculine lodges. The important new development however is that the Droit Humain is no longer alone in the field. Since 1981, a Women's Grand Lodge of Belgium (about 2000 members) is present as well, federating the exclusively feminine lodges that had been started out of French initiatives on Belgian soil since 1974. Formerly male lodges (in the city of Ghent mainly) have left the Grand Orient to operate on a mixed basis, without any grand lodge attachment or with an affiliation to the mixed Grand Orient du Luxembourg (which counts three Belgian lodges having about 150 members all

\footnotetext{
${ }^{45}$ Marinette Bruwier Marie-Louise Pirotte, "Le rôle de la loge « Les Amis Philanthropes » dans la création du « Droit Humain » en Belgique (1910-1912)", Visages de la franc-maçonnerie belge du XVIIIe au XX siècle, Hervé Hasquin ed. (Brussels : Editions de l’Université, 1983), 257-271.

${ }^{46}$ Tyssens, "Le discours masculin sur la franc-maçonnerie des femmes en Belgique (1912-1967): la régression des progressistes?", Les femmes et la franc-maçonnerie. Des Lumières à nos jours, XXe et XXIe siècles, C. Revauger ed. (Brussel : La Pensée et les Hommes, 2012), 249-262.

${ }^{47}$ The number of the RGLB is probably less than that, due to the double memberships that are quite frequent in that grand lodge whereas e.g. the Grand Orient does not allow for an affiliation to more than one of its lodges. The Droit Humain allows double affiliations too but they are less frequent than the Regular Grand Lodge.
} 
together). Within the Droit Humain, dissatisfaction with the ways of working of the order allegedly the centralizing of authority in Paris- led to a movement of splits in lodges and the creation of new ones under a loosely tied confederation of lodges named Lithos (which counts about 650 members but is still growing, members also coming in from other grand lodges than the Droit Humain).

So it is clear that a certain fragmentation of Belgian freemasonry has taken place after the Second World War, mainly during the last decades, even if it has not become as outspoken as in France. Paradoxically, the last 25 years have generated a reverse tendency as well, not by dint of a fusion between different "Latin" or "liberal" grand lodges, but through the 1989 friendship treaty which comprises the four major Belgian masonic bodies, with the exception of the London-oriented Regular Grand Lodge and the new Lithos confederation. And even at that level things are changing. Grand Masters of the Grand Orient and the Regular Grand Lodge appeared together on television programmes, both acknowledging the fact that the respective projects are not the same, one spiritual and traditional, the other rather focused on active citizenship and laïcité, but nevertheless, the spirit is no longer one of hostility but rather one of informal, benevolent cooperation. As for Lithos, relationships with the older masonic bodies have not been formalized yet, its creation still being quite recent and its deliberate lack of central authority making the conclusion of treaties with the other grand lodges less evident: on an informal level though, contacts do exist and members visit mutually without significant problems. Apparently, in Belgium as well as in several other countries, masons are gradually leaving the older exclusive models in favor of a more pluralist approach, timidly perhaps, but nevertheless.

\section{Bibliography}

Abeele, Andries van den. De Kortrijkse vrijmetselaarsloge L'Amitié 1803-1833. Kortrijk: De Leiegouw, 1989.

Agulhon, Maurice. Pénitents et Francs-Maçons de l'ancienne Provence. Paris : Fayard, 1968.

Balthazar, Herman. "De Gentse brandhaard. Orangisme en vrijmetselarij”. In Van Wijsheid met Vreugd gepaard. Twee eeuwen vrijmetselarij in Gent en Antwerpen. Edited by Jeffrey Tyssens. Brussels / Ghent: Marot / Tijdsbeeld, 2003.

Bartier, John. "L'Université libre de Bruxelles au temps de Théodore Verhaegen”. In Lä̈cité et franc-maçonnerie. Edited by John Bartier. Brussels: Editions de l’Université, 1981.

Bartier, John. "Théodore Verhaegen, la franc-maçonnerie et les sociétés politiques". In Laïcité et franc-maçonnerie. Edited by John Bartier. Brussels: Editions de l’Université, 1981. 
Bartier, John. "La condamnation de la franc-maçonnerie par les évêques belges en 1837". In Lä̈cité et franc-maçonnerie. Edited by John Bartier. Brussels : Editions de l'Université, 1981.

Boudin, Hugh. "Goblet d'Alviella et le protestantisme libéral". In Eugène Goblet d'Alviella, historien et franc-maçon. Edited by Alain Dierkens. Brussels : Editions de l'Université, 1995.

Bruwier, Marinette and Marie-Louise Pirotte. "Le rôle de la loge «Les Amis Philanthropes » dans la création du « Droit Humain » en Belgique (1910-1912)". In Visages de la franc-maçonnerie belge du XVIIIe au XX siècle. Edited by Hervé Hasquin. Brussels : Editions de l'Université, 1983.

Daled, Pierre F. Spiritualisme et matérialisme au XIXe siècle. L'Université Libre de Bruxelles et la religion. Brussels : Editions de l'Unversité, 1998.

Desmed, Roger. "L'évolution du sentiment religieux chez les Francs-Maçons belges entre 1830 et 1914. L'exemple des loges bruxelloises". Problèmes d'histoire $d u$ christianisme VII (1978) : 57-86.

Ferrer Benimelli, José Antonio. "Franc-maçonnerie et Eglise catholique. Motivations politiques des premières condamnations papales". Dix-huitième Siècle 19 (1987) : 719.

Fransen, Jan. "Het Humanistisch Verbond: ontstaan, uitbreiding en crisis (1951-1961)". Belgisch Tijdschrift voor Nieuwste Geschiedenis 3-4 (1998): 499-525.

Hasquin, Hervé dir. Het culturele leven in onze provincies in de $18^{e}$ eeuw. Brussels: Gemeentekrediet, 1983.

Isterdael, Herman van. Geschiedenis van de vrijmetselaarsloge La Discrète Impériale te Aalst (1764-1786). Aalst, 2014.

Lemaire, Jacques. "L'abandon du Grand Architecte de l'Univers par le Grand Orient de Belgique". In Studia Latomorum et Historica. Mélanges offerts à Daniel Ligou. Edited by Charles Porset. Paris : H. Champion, 1998.

Lemaire, Jacques. "Franc-maçonnerie et religion en Flandre et dans les pays-bas autrichiens pendant le XVIIIe siècle". In Franc-maçonnerie et religions dans l'Europe des Lumières. Edited by Charles Porset and Cécile Révauger. Paris : Champions, 2006.

Miroir, André. "Franc-maçonnerie et politique en régime censitaire. Essai sur l'abrogation de l'article 135 des Statuts et règlements généraux (1854-1870)". In Visages de la franc-maçonnerie belge du XVIIIe au XX siècle. Edited by Hervé Hasquin. Brussels : Editions de l'Université, 1983.

Miroir, André. "La franc-maçonnerie et la guerre d'Espagne (1939-1939)". Belgisch Tijdschrift voor Nieuwste Geschiedenis 1-2 (1987) : 481-495.

Saunier, Eric. 'La Franc-maçonnerie et l'Etat napoléonien : de l'instrumentalisation à la recomposition". In La Franc-maçonnerie sous 'Empire. Un âge d'or? Edited by Pierre Mollier. Paris: Dervy, 2007. 
Schampheleire, Hugo de. De Antwerpse vrijmetselaars in de $18^{e}$ eeuw. Antwerp. Ontwikkeling, 1969.

Schampheleire, Hugo de. Histoire de la franc-maçonnerie belge depuis 1830. Un siècle et demi de Grand orient de Belgique. Tome 1 : période de 1830-1914. Brussels : GOB, 1987.

Schelden, Bertrand van der. La Franc-Maçonnerie belge sous le régime autrichien (17211794). Etude historique et critique. Louvain : Librairie Universitaire, 1923.

Schrans, Guy. Vrijmetselaars te Gent in de XVIIIde eeuw. Ghent: Liberaal Archief, 1997.

Schrader, Fred E. Augustin Cochin et la République française. Paris : Seuil, 1992.

Stengers, Jean. "De filosofische en godsdienstige opvattingen van Verhaegen". In PierreThéodore Verhaegen 1796-1862. Brussels: VUBPress, 1996.

Tyssens, Jeffrey. "Sous le signe du progrès. Une histoire de la Loge gantoise «La Liberté N4»>". In R:. L: La Liberté. Or:. de Gand, 5866-5991. Gent : 1991.

Tyssens, Jeffrey. Strijdpunt of pasmunt? Levensbeschouwelijk links en de schoolkwestie, 1918-1940. Brussel: VUBPress, 1993.

Tyssens, Jeffrey. Om de schone ziel van 't kind ... Het onderwijsconflict als een breuklijn in de Belgische politiek. Gent, Provinciebestuur Oost-Vlaanderen : Liberaal Archief, 1998.

Tyssens, Jeffrey. "Vrijmetselarij", Nieuwe Encyclopedie van de Vlaamse Beweging. Tielt: Lannoo, 1998.

Tyssens, Jeffrey. "Pratiques funéraires. La sécularisation des derniers instants". In Bruxelles. Les francs-maçons dans la cité. Directed by A. Despy-Meyer. Ghent: Tijdsbeeld, 2000.

Tyssens, Jeffrey. "'Van Wijsheid met Vreugd gepaard'. Twee eeuwen vrijmetselarij in Gent en Antwerpen". Van Wijsheid met Vreugd gepaard. Twee eeuwen vrijmetselarij in Gent en Antwerpen. Edited by Jeffery Tyssens. Brussels / Ghent: Marot / Tijdsbeeld, 2003.

Tyssens, Jeffrey. “Adorateurs du diable'. Over vrijmetselarij en levensbeschouwing”. Van Wijsheid met Vreugd gepaard. Twee eeuwen vrijmetselarij in Gent en Antwerpen. Edited by Jeffery Tyssens. Brussels / Ghent: Marot / Tijdsbeeld, 2003.

Tyssens, Jeffrey. "Aspects de la sensibilité libérale dans les loges belges pendant les premières décennies du XIXe siècle”. Lumières 7 (2006) : 177-201.

Tyssens, Jeffrey. "Sur les rites funéraires de la franc-maçonnerie belge du XIXe siècle », REHMLAC 3, no. 1 (mayo-noviembre 2011): 160-182. Available in http://revistas.ucr.ac.cr/index.php/rehmlac/article/view/6591/6282

Tyssens, Jeffrey. "Le discours masculin sur la franc-maçonnerie des femmes en Belgique (1912-1967): la régression des progressistes?”. Les femmes et la franc-maçonnerie. Des Lumières à nos jours, XXe et XXIe siècles. Edited by Cécile Révauger. Brussel : La Pensée et les Hommes, 2012. 
Tyssens, Jeffrey and Marie-Pierre Verhaegen. "De dood van Pierre-Théodore Verhaegen". In Pierre-Théodore Verhaegen (1796-1862). Brussel: VUBPress, 1996.

Sande, Anton van de. Vrijmetselarij in de lage landen. Een mysterieuze broederschap zonder geheimen. Nijmegen: Walburg Pers, 2001.

Vantomme, Raoul. La vie de la loge Les Trois Niveaux établie à l'Orient d'Ostende depuis 1784. Ostend, 1986. 